\title{
PENGARUH PROFITABILITAS TERHADAP NILAI PERUSAHAAN DENGAN KEBIJAKAN DIVIDEN SEBAGAI VARIABEL MODERATING
}

\author{
Hendy Satria \\ Sekolah Tinggi Ilmu Ekonomi (STIE) Pembangunan Tanjungpinang \\ pinanghmi3@gmail.com
}

\begin{abstract}
Abstrak: Penelitian ini bertujuan untuk mengetahui profitabilitas terhadap nilai perusahaan dengan kebijakan dividen sebagai variabel moderating (Studi Kasus di Bursa Efek Indonesia). Penelitian ini menggunakan metode deskriptif dengan menggunakan analisis kuantitaif. Data yang digunakan adalah data sekunder berupa laporan keuangan perusahaan manufaktur tahun 2017-2019 yang telah diaudit dan dipublikasikan. Populasi dalam penelitian ini adalah sektor industry barang dan konsumsi yang terdaftar di BEI tahun 2017-2019 sebanyak 40 perusahaan. Pemilihan sampel dengan menggunakan purposive sampling sehingga diperoleh 12 perusahaan. Berdasarkan hasil penelitian dapat disimpulkan bahwasanya terdapat pengaruh profitabilitas terhadap nilai perusahaan kebijakan dividen sebagai Variabel Moderating, hal ini terbukti dari hasil uji t analisis modereting dimana nilai t hitung 3,680 > t tabel 2,03011 dan nilai signifikansi 0,015 <0,05 yang berarti Kebijakan Dividen merupakan variabel moderating dalam hubungan antara Profitabilitas terhadap Nilai Perusahaan.
\end{abstract}

Kata Kunci: Profitabilitas, Kebijakan Dividen, Nilai perusahaan

\begin{abstract}
This study aims to determine the profitability of firm value with dividend policy as a moderating variable (Case Study on the Indonesia Stock Exchange). This study uses a descriptive method using quantitative analysis. The data used is secondary data in the form of audited and published financial statements of manufacturing companies 2017-2019. The population in this study is the goods and consumption industry sector listed on the IDX in 20172019 as many as 40 companies. The sample selection used purposive sampling in order to obtain 12 companies. Based on the results of the study, it can be concluded that there is an effect of profitability on the firm value of dividend policy as a Moderating Variable. This is evident from the results of the moderating analysis $t$ test where the $t$ value is 3.680>t table 2.03011 and $a$ significance value of $0.015<0.05$, which means that dividend policy is a moderating variable in the relationship between Profitability and Firm Value.
\end{abstract}

Keywords: Profitability, Dividend Policy, Firm Value

\section{PENDAHULUAN}

Perkembangan perusahaan manufaktur cukup pesat, hal ini dapat terlihat dari jumlah perusahaan manufaktur yang terdaftar di Bursa Efek Indonesia (BEI) dari periode ke periodenya semakin bertambah, sehingga tidak menutup kemungkinan perusahaan ini sangat dibutuhkan masyarakat sehingga prospeknya akan menguntungkan di masa kini maupun di masa yang akan datang.
Selain itu dapat dikatakan bahwa persaingan industri manufaktur menjadi semakin ketat karena banyaknya produk impor yang dengan mudahnya masuk ke pasar Indonesia dan menjadi alternatif pilihan para konsumen di Indonesia serta semakin maraknya produkproduk ilegal yang menjadi hambatan bagi perusahaan di industri manufaktur untuk menguasai pasar. Daya saing produk manufaktur semakin melemah. Di dalam 
negeri, produk manufaktur seperti elektronika rumah tangga kalah bersaing dengan produk impor, apalagi diperburuk dengan banyaknya produk ilegal. Di pasar internasional, produk tekstil dan produk kayu yang masih menjadi primadona ekspor kalah bersaing dengan produk dari Cina dan negara ASEAN lainnya.

Hal ini mendorong masing-masing perusahaan untuk melakukan berbagai inovasi dan strategi bisnis agar terhindar dari kebangkrutan. Memilih perusahaan yang baik dapat dilihat dari berbagai indikator, salah satunya yaitu nilai perusahaan.Nilai perusahaan dianggap sangat penting karena dapat mencerminkan keadaan suatu perusahaan. Dalam penelitian ini nilai perusahaan dapat diukur dengan Price to Book Value (PBV). Price to book value merupakan rasio yang dapat digunakan untuk mengukur nilai perusahaan.

Ada banyak faktor yang dapat meningkatkan nilai suatu perusahaan, antara lain profitabilitas dan kebijakan dividen. Menurut Kasmir (2010) dalam (Sari, 2015) profitabilitas merupakan faktor yang dapat mempengaruhi nilai perusahaan. Jika manajer mampu mengelola perusahaan dengan baik maka biaya yang akan dikeluarkan oleh perusahaan akan menjadi lebih kecil sehingga laba yang dihasilkan menjadi lebih besar.

Profitabilitas merupakan rasio kinerja yang mengukur laba perusahaan, rasio ini sering digunakan sebagai indikator fundamental perusahaan. Rasio profitabilitas dapat digunakan sebagai salah satu sumber informasi bagi perusahaan dan investor untuk mengetahui kinerja perusahaan. Kinerja keuangan yang baik mengindikasikan bahwa manajer mengelola dana dan juga sumber dayanya dengan baik. Kinerja keuangan yang baik memberikan signal yang positif bagi investor, karena mencerminkan besarnya laba yang diperoleh perusahaan. Terdapat beberapa rasio antara lain net profit margin (NPM), gross profit margin (GPM), return on assets (ROA), return on equity (ROE), earning per share (EPS) (Sari, 2015)

Kebijakan dividen merupakan salah satu faktor yang dapat mempengaruhi nilai perusahaan. Kebijakan dividen sering dianggap sebagai bagian dari keputusan pembelanjaan, khususnya pembelanjaan internal. Hal ini terjadi karena besar kecilnya dividen yang dibayarkan perusahaan akan mempengaruhi sumber dana internal perusahaan, yaitu laba ditahan. Semakin besar dividen yang dibayarkan kepada pemegang saham, semakin kecil laba yang ditahan, dan sebaliknya. Penentuan besaran bagian laba bersih perusahaan yang akan dibagikan sebagai dividen merupakan kebijakan manajemen perusahaan, serta akan mempengaruhi nilai perusahaan dan harga saham.(Mediasi \& Sedana, 2015).

Alasan penulis mengambil objek penelitian pada perusahan manufaktur sektor industri barang konsumsi karena perusahaan manufaktur sektor industri barang konsumsi 
merupakan salah satu sektor dalam perusahaan yang terdaftar di Bursa Efek Indonesia yang memiliki peluang tumbuh berkembang yang besar.Hal ini disebabkan oleh besarnya permintaan pasar dalam sektor ekonomi sehingga dapat memacu pertumbuhan perekonomian yang cukup pesat.

Berdasarkan dari banyaknya penelitianpenelitian mengenai variabel-variabel yang berpengaruh terhadap nilai perusahaan yang menunjukkan hasil yang tidak konsisten, memotivasi peneliti untuk meneliti kembali faktor yang mempengaruhi nilai perusahaan. Perbedaan menonjol dari peneltian terdahulu yaitu terletak pada objek variabel pemoderasinya yang digunakan. Berdasarkan dari uraian diatas maka peneliti tertarik dan termotivasi untuk meneliti faktor yang mempengaruhi nilai perusahaan dengan judul "Pengaruh Profitabilitas Terhadap Nilai Perusahaan dengan Kebijakan Dividen sebagai Variabel Moderating Pada Perusahaan Manufaktur Yang Terdaftar Di Bursa Efek Indonesia Tahun 20172019."

\section{METODE PENELITIAN}

Metode yang digunakan dalam penelitian ini yaitu metode deskriptif dengan pendekatan kuantitatif yaitu jenis penelitian yang menguraikan serta menggambarkan suatu kondisi permasalahan tertentu yang diuraikan secara bergantian untuk setiap variabel penelitian. Sedangkan kuantitatif itu menekankan pada pengujian teori-teori melalui pengukuran variabel-variabel penelitian dengan angka dan juga melakukan analisis data dengan prosedur statistik (Timotius, 2017).

\section{Jenis Data Dan Sumber Data}

Jenis data yang digunakan oleh peneliti adalah data sekunder. Data yang digunakan dalam penelitian yaitu laporan tahunan perusahaan yang tercatat pada periode 2017 2019. Data tersebut dapat diperoleh dengan mengakses situs www.idx.co.id, untuk mendapatkan data profitabilitas, nilai perusahaan, dan kebijakan dividen.

Teknik Pengumpulan Data

Dalam penelitian ini peneliti menggunakan teknik pengumpulan data berupa dokumentasi dan studi pustaka.

\section{Populasi dan Sampel}

\section{Populasi}

Populasi yang digunakan dalam penelitian ini ditekankan pada perusahaan manufaktur sektor industri barang konsumsi yang terdaftar di Bursa Efek Indonesia dan melampirkan laporan keuangan dari tahun 2017-2019 yaitu sebanyak 40 perusahaan.

\section{Sampel}

Sampel dalam penelitian ini adalah perusahaan sektor industri barang konsumsi yang terdaftar di BEI mulai tahun 2017 sampai dengan tahun 2019. Teknik penelitian ini menggunakan purposive sampling, yaitu penarikan sampel sampel dengan pertimbangan tertentu. Sample pada penelitian ini adalah 12 perusahaan. 


\section{Definisi Operasional Variabel}

\section{Variabel dependen}

Menurut (Sugiyono, 2017) variabel dependen atau disebut juga sebagai variabel output, kriteria, konsekuen. Dalam bahasa indonesia sering disebit sebagai variabel terikat. Variabel terikat merupakan variabel yang dipengaruhi atau yang menjadi akibat, karena adanya variabel bebas. Dalam penelitian ini variabel yang digunakan adalah nilai perusahaan.

\section{Variabel independen}

Menurut (Sugiyono, 2017) variabel independen atau sering disebut sebagai variabel stimulasi, prediktor, antecedent. Dalam bahasa indonesia sering disebut sebagai variabel bebas. Variabel bebas adalah merupakan variabel yang mempengaruhi atau yang menjadi sebab perubahannya atau timbulnya variabel dependen (terikat). Dalam penelitian ini variabel independen yang digunakan adalah profitabilitas.

\section{Variabel moderating}

Menurut (Ghozali, 2013) variabel moderating adalah variabel yang bertindak sebagai variabel kedua dimana dengan adanya variabel moderating ini akan memperkuat ataupun memperlemah hubungan antara variabel independen lainnya terhadap variabel dependen. Variabel moderating dalam penelitian ini adalah kebijakan dividen.

\section{Teknik Pengolahan Data}

Setelah data dikumpulkan, langkah seterusnya yang dilakukan adalah mengolah data tersebut menjadi informasi yang bisa digunakan untuk tujuan penelitian (Agus \& Riyanto, 2013) Ada 3 langkah-langkah untuk mengolah data:

1. Editing, yaitu pemeriksaan kembali datadata tentang laporan keuangan yang diperoleh terutama dari segi kelengkapan, kejelasan data, keserasian dan keselarasan antara yang satu dengan yang lainnya, relevansi dan keseragaman baik satuan maupun kelompok.

2. Organizing, yaitu menyusun dan mensistematika data laporan keuangan yang diperoleh dalam kerangka uraian yang telah direncanakan.

3. Analyzing, yaitu tahapan analisis data tentang laporan keuangan dengan menggunakan analisis rasio likuiditas, rasio profitabilitas dalam proses penyederhanaan ke dalam bentuk yang lebih mudah dibaca dan diinterpretasikan.

\section{Teknik Analisis Data}

Teknik analisis data merupakan cara mengolah data yang telah diperoleh dari lapangan. Alat analisis data yang digunakan dalam penelitian ini adalah dengan menggunakan aplikasi program SPSS (Statistical Program for Social Science) versi 21.0 for Windows. 


\section{Uji Asumsi Klasik}

\section{Uji Normalitas}

Uji normalitas dapat dilakukan untuk menguji apakah nilai residu yang telah distandarisasi pada model regresi berdistribusi normal atau tidak.Nilai residual dikatakan berdistribusi normal jika nilai residual terstandarisasi tersebut sebagian besar mendekati nilai rataratanya. Untuk mendeteksi apakah nilai residual terstandarisasi atau tidak, maka dalam penelitian ini akan menggunakan metode analisis grafik, (normal p-plot of regression standarized residual) dan metode statistic (kormology-smirnov) untuk melakukan uji normalitas data penelitian (Suliyanto, 2011).

\section{Uji Autokorelasi}

Persamaan regresi yng benar adalah yang tidak memiliki masalah autokorelasi.Uji autokorelasi digunakan untuk mengetahui ada atau tidaknya korelasi yang terjadi antara kesalahan pengganggu periode $\mathrm{t}$ (berada) dan kesalahan pengganggu periode t.(Sunyoto, 2013).

\section{Uji Multikolonieritas}

Menurut (Ghozali \& Imam, 2013) multikolonieritas merupakan fenomena adanya korelasi yang sempurna antara satu variabel bebas dengan variabel bebas lain. Uji multikolinearitas bertujuan untuk menguji apakah model regresi ditemukan adanya korelasi antar variabel bebas (independen). Model regresi yang baik seharusnya tidak terjadi korelasi di antara variabel independennya. Metode untuk menguji adanya multikolinearitas dapat dilihat

\section{Uji Heteroskedastistas}

Uji Heterokedastisitas bertujuan untuk menguji apakah dalam model regresi tersebut ada kesamaan atau tidaknyavarian dari residual satu pengamatan ke pengamatan yang lain.

\section{Uji hipotesis}

\section{Moderated Regression Analiysis}

Menurut (Ghozali, 2013) Moderated Regression Analysis (MRA) adalah metode yang menggunnakan pendekatan analitik yang mempertahankan integritas sampel dan memberikan dasar untuk mengontrol pengaruh variable moderasi.

\section{Uji Determinasi $\left(\mathbf{R}^{2}\right)$}

Menurut Ghozali (2013) koefisien determinasi (R2) pada intinya mengukur seberapa jauh kemampuan model dan menerangkan variasivariabel dependen.

\section{Uji Parsial (Uji t)}

Menurut Priyatno (2012) uji t digunakan untuk mengetahui apakah variabel independen berpengaruh secara signifikan atau tidak terhadap variabel dependen.

\section{HASIL DAN PEMBAHASAN}

\section{Uji Normalitas}

Uji normalitas adalah untuk menguji apakah dalam model regresi variabel dependen, variabel independen atau keduanya berdistribusi normal atau tidak. 
Tabel 1

Uji Normalitas

One-Sample Kolmogorov-Smirnov Test

\begin{tabular}{|ll|r|}
\hline & & $\begin{array}{c}\text { Unstandardized } \\
\text { Residual }\end{array}$ \\
\hline Normal Parameters ${ }^{\mathrm{a}}$ & Mean & 36 \\
& Std. & .0000000 \\
& Deviatio & 18.85507290 \\
& $\mathrm{n}$ & \\
Most Extreme Differences & Absolute & .122 \\
& Positive & .122 \\
& Negative & -.092 \\
Kolmogorov-Smirnov Z & & .577 \\
Asymp. Sig. (2-tailed) & & .894 \\
\hline
\end{tabular}

a. Test distribution is Normal.

Berdasarkan hasil analisis metode One Sample Kolmogorov Smirnov pada table diatas terlihat bahwa nilai signifikasi sebesar 0,894>0,05 sehingga data berdistribusi normal

\section{Uji P-Plot}

Dalam uji P-Plot ketentuan yang digunakan yaitu jika data menyebar disekitar garis diagonal dan mengikuti arah garis diagonal maka berdistribusi normal.

\section{Uji Normalitas P-Plot}

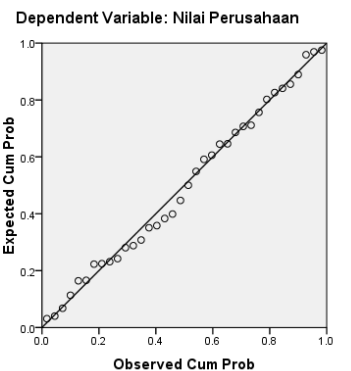

Gambar 1

Berdasarkan hasil pada tersebeut terlihat bahwa titik-titik menyebar dan mengikuti garis diagonal, sesuai dengan ketentuan maka data berdistribusi normal.

\section{Histogram}

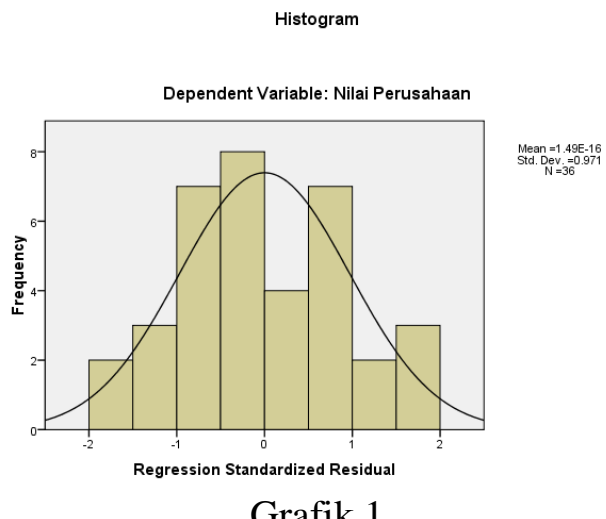

Berdasarkan grafik histogram pada gambar di atas menunjukkan bahwa pola berdistribusi normal, tetapi jika kesimpulan normal tidaknya data hanya dilihat dari grafik histogram.

\section{Uji Multikolineritas}

Tabel 2

Uji Multikolineritas

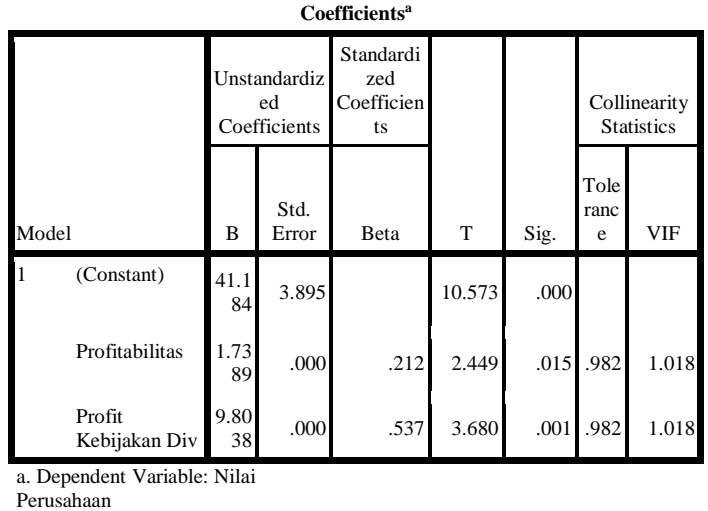

Pada tabel 2 diatas Nilai tolerance $\mathrm{X}$ (Profitabilitas) sebesar 0,982>0.1 dan nilai VIF sebesar $1,018<10$, nilai tolerance $\mathrm{Z}$ (Kebijakan Dividen) sebesar 0,982>0.1 dan nilai VIF sebesar $1,018<10$. Berdasarkan hasil pengujian tidak ada satu variabel bebas yang memiliki nilai tolerance $<0.1$ dan tidak ada nilai VIF >10 sehingga berdasarkan ketentuan dapat disimpulkan bahwa model 
regresi tidak terjadi multikolineritas antar variabel bebas. Sehingga diindikasikan bahwa tidak terjadi multikolineritas antara variabel bebas dalam penelitian.

\section{Uji Heterokedastisitas}

Uji heteroskedastisitas bertujuan untuk mengetahui ada tidaksamaan varian dari residul pada model regresi.

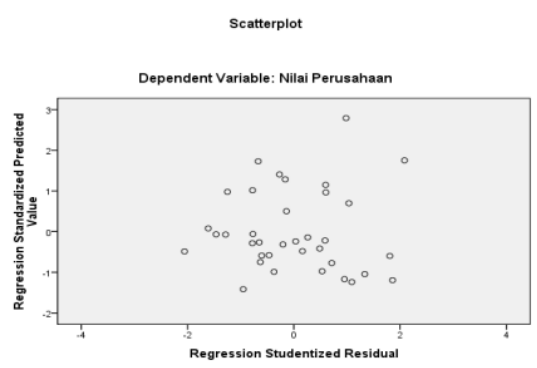

Gambar 1

Pada gambar diatas dapat dilihat sebaran titik-titik yang acak, baik diatas maupun dibawah angka 0 dari sumbu y, titik tidak hanya mengumpul di atas atau di bawah saja , penyebaran titik-titik data tidak berpola dan penyebaran titik-titik data tidak membentuk pola bergelombang melebar kemudian menyempit dan melebar kembali melebar sehingga dapat disimpulkan bahwa tidak terjadi heteroskedastisitas dalam persamaaan ini.

\section{Uji Autokorelasi}

Uji Autokorelasi bertujuan untuk menguji apakah dalam suatu model regresi linier ada korelasi antara residual (kesalahan pengganggu) pada periode $t$ dengan residual pada periode t-1 (sebelumnya).
Tabel 3

Uji Autokorelasi

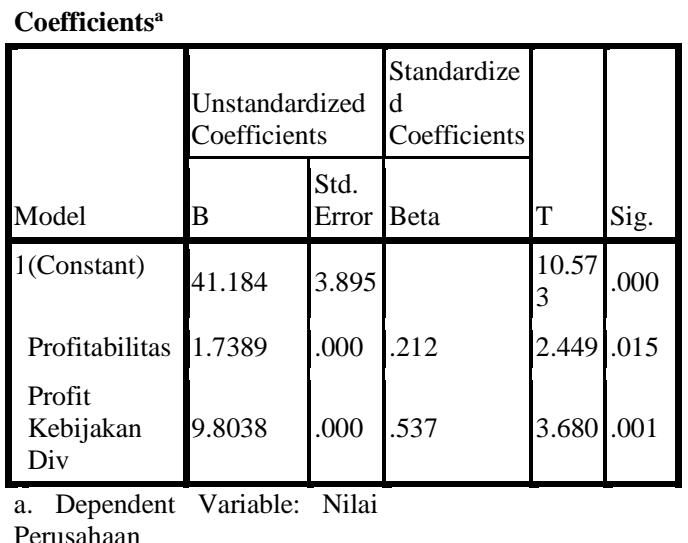

Model Summary ${ }^{b}$

\begin{tabular}{l|r|r|r|r|r|}
\hline $\begin{array}{l}\text { Mo } \\
\text { del }\end{array}$ & \multicolumn{1}{c|}{$\mathrm{R}$} & $\begin{array}{r}\mathrm{R} \\
\text { Square }\end{array}$ & $\begin{array}{r}\text { Adjusted } \\
\text { R Square }\end{array}$ & $\begin{array}{c}\text { Std. Error of the } \\
\text { Estimate }\end{array}$ & $\begin{array}{c}\text { Durbin- } \\
\text { Watson }\end{array}$ \\
\hline 1 & $.553^{\mathrm{a}}$ & .306 & .264 & 18.00642 & 1.466 \\
\hline
\end{tabular}
a. Predictors: (Constant), Profit Kebijakan Div,
Profitabilitas
b. Variable: Nilai Perusahaan
Vependent

Hasil pengujian autokorelasi pada tabel diatas menunnjukkan bahwa nilai DW yang diperoleh sebesar 1,183 nilai tabel $\mathrm{du}$ diperoleh berdasarkan dari jumlah data $n$ sebanyak 36, sehingga nilai tabel du sebesar 1,466. Sehingga $1,411<1,466<1,525$ dapat diindikasikan bahwa tidak terjadi autokorelasi. Data yang tidak mengalami autokorelasi dinyatakan bebas dari residual (pengganggu) dimana data tidak ada korelasi pada periode $\mathrm{t}$ dengan periode $\mathrm{t}-1$ (periode sebelumnya).

\section{Uji t Moderating}

Uji t moderating dilakukan untuk menguji apakah kebijakan dividen sebagai variabel moderating dapat memperkuat atau memperlemah hubungan antara profitabilitas terhadap nilai perusahaan. 
Koefisien Jalur : Mengacu pada tabel 4.4 hasil uji $\mathrm{t}$ untuk variabel moderating menunjukkan bahwa variabel kebijakan dividen merupakan variabel moderating dan mampu memperkuat dalam hubungan antara Profitabilitas terhadap Nilai Perusahaan. Hal ini dapat dibuktikan dengan diperoleh nilai $\mathrm{t}$ hitung 3,680> $\mathrm{t}$ tabel 2,03011 dan nilai signifikansi 0,001<0,05 maka Ho ditolak dan Ha diterima, yang berarti Kebijakan Dividen merupakan variabel moderating dalam hubungan antara Profitabilitas terhadap Nilai Perusahaan. Nilai $\mathrm{t}$ hitung positif artinya berpengaruh positif, yaitu pemahaman internet dapat memperkuat hubungan antara Profitabilitasterhadap Nilai Perusahaan.Jadi, dapat disimpulkan bahwa hipotesis ketiga diterima.

\section{Uji Parsial (Uji t)}

Pengujian ini digunakan untuk mengetahui apakah variabel independen berpengaruh secara signifikan atau tidak terhadap variabel dependen.

1. Profitabilitas terhadap Nilai Perusahaan

Tabel 4

nilai tabel

\begin{tabular}{|c|c|c|c|c|c|}
\hline \multirow[b]{3}{*}{ Model } & \multicolumn{3}{|c|}{ Coefficients $^{\mathbf{a}}$} & \multirow[b]{3}{*}{$\mathrm{T}$} & \\
\hline & \multicolumn{2}{|c|}{$\begin{array}{l}\text { Unstandardized } \\
\text { Coefficients }\end{array}$} & $\begin{array}{l}\text { Standardized } \\
\text { Coefficients }\end{array}$ & & \multirow[b]{2}{*}{ Sig. } \\
\hline & $\mathrm{B}$ & $\begin{array}{l}\text { Std. } \\
\text { Error }\end{array}$ & Beta & & \\
\hline 1 (Constant) & 61.287 & 7.958 & & 7.701 & .031 \\
\hline $\begin{array}{l}\text { Profitabilita } \\
\mathrm{s}\end{array}$ & 1.329 & .590 & .360 & 2.253 & .000 \\
\hline
\end{tabular}

a. Dependent Variable: Nilai

Perusahaan

Berdasarkan tabel dapat disimpulkan bahwa nilai $t_{\text {tabel }}$ diperoleh berdasarkan jumlah $\mathrm{n}$ (jumlah data) $=36$, sedangkan jumlah nilai signifikan sebesar 5\%, sehingga nilai variabel Profitabilitas diperoleh nilai $\mathrm{t}_{\text {hitung }} 2$ 2,253> $\mathrm{t}_{\text {tabel }} 2,03011$ dan nilai signifikan $0.000<0.05$. Berdasarkan kedua nilai tersebut maka dapat disimpulkan bahwa Profitabilitas berpengaruh signifikan terhadap Nilai Perusahaan.

2. Kebijakan Dividen terhadap Nilai Perusahaan

Tabel 5

Nilai $t_{\text {tabel }}$ Coefficients $^{\mathrm{a}}$

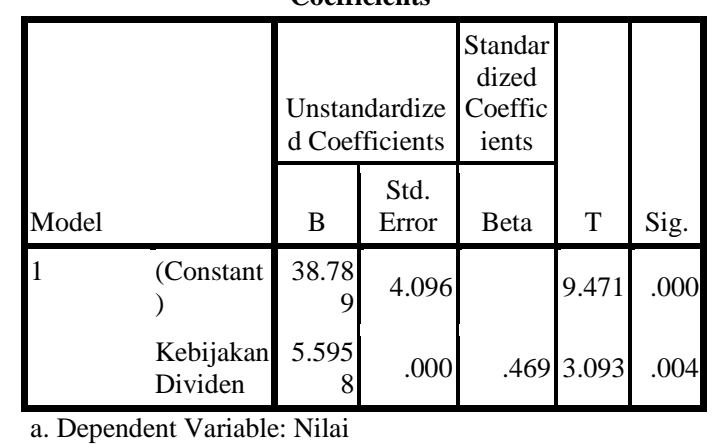
Perusahaan

Berdasarkan tabel diatas dapat disimpulkan bahwa nilai $t_{\text {tabel }}$ diperoleh berdasarkan jumlah $\mathrm{n}$ (jumlah data) $=36$, sedangkan jumlah nilai signifikan sebesar $5 \%$, sehingga nilai variabel Kebijakan Dividen diperoleh nilai thitung 3,093>

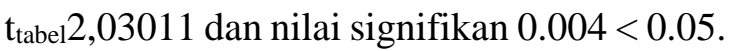
Berdasarkan kedua nilai tersebut maka dapat disimpulkan bahwa bahwa Kebijakan Dividen berpengaruh signifikan terhadap Nilai Perusahaan.

\section{Koefisiensi Determinasi $\boldsymbol{R}^{2}$}

Uji ini untuk mengetahui besarnya variabel independen dalam mempengaruhi variabel dependen dapat diketahui melalui koefisien determinasi yang ditunjukkan oleh nilai $R$ Square. 
Tabel 6

Nilai R square

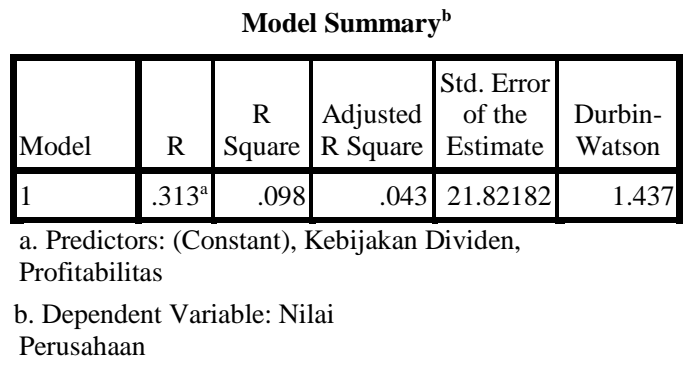

Dari tabel diatas besarnya $\mathrm{R}$ Square berdasarkan hasil analisis diperoleh sebesar 0,980 . Dengan demikian besarnya pengaruh yang diberikan oleh profitabilitas terhadap nilai perusahaan melalui kebijakan dividen adalah sebesar $9,8 \%$ dan sisanya $91,2 \%$ dipengaruhi oleh variabel lain yang tidak diteliti pada penelitian ini.

Berikut berguna untuk mengetahui seberapa besar persentase pengaruh variabel independen dan variabel moderating menjelaskan pengaruh yang terjadi terhadap variabel independen. Hasil perhitungan koefisien determinasi moderating dapat dilihat pada tabel dibawah ini sebagai berikut:

Tabel 7

Nilai R Square (R2)

Model Summary ${ }^{b}$

\begin{tabular}{|l|c|r|r|r|r|}
\hline Model & $\mathrm{R}$ & $\begin{array}{c}\mathrm{R} \\
\text { Square }\end{array}$ & $\begin{array}{c}\text { Adjusted } \\
\text { R Square }\end{array}$ & $\begin{array}{c}\text { Std. Error } \\
\text { of the } \\
\text { Estimate }\end{array}$ & $\begin{array}{c}\text { Durbin- } \\
\text { Watson }\end{array}$ \\
\hline 1 & $.553^{\mathrm{a}}$ & .306 & .264 & 18.00642 & 1.566 \\
\hline
\end{tabular}

a. Predictors: (Constant), Profit Kebijakan Div,

Profitabilitas

b. Dependent Variable: Nilai

Perusahaan

Berdasarkan tabel diatas diperoleh nilai $\mathrm{R}$ square (R2) sebesar 0,306. Hal ini berarti bahwa persentase pengaruh Profitabilitassebagai variabel independen dan
Kebijakan Dividen sebagai variabel moderating sebesar $30,6 \%$ terhadap Nilai Perusahaan, sedangkan sisanya sebesar $69,4 \%$ dipengaruhi oleh variabel lain di luar penelitian ini.

\section{PENUTUP}

\section{Kesimpulan}

Berdasarkan hasil analisis dan pembahasan mengenai pengaruh profitabilitas terhadap nilai perusahaan dengan kebijakan dividen sebagai variabel moderating, maka dapat diambil kesimpulan sebagai berikut :

1. Hasil penelitian membuktikan bahwa profitabilitas berpengaruh postif terhadap terhadap nilai perusahaan. Hal ini dibuktikan melalui analisis Uji $\mathrm{T}$ menunjukkan nilai variabel Profitabilitas diperoleh $\mathrm{t}_{\text {hitung }} 2,253>\mathrm{t}_{\text {tabel }} 2,03011$ dan nilai signifikan $0.000<0.05$. Berdasarkan kedua nilai tersebut mengindikasikan bahwa semakin tinggi angka profitabilitas maka nilai perusahaan juga akan ikut membaik.

2. Hasil penelitian membuktikan bahwa kebijakan dividen berpengaruh postif terhadap terhadap nilai perusahaan. Hal ini dibuktikan melalui analisis $\mathrm{Uji} \mathrm{T}$ yang menunjukkan nilai variabel Kebijakan Dividen diperoleh nilai $t_{\text {hitung }} 3,093>t_{\text {tabel }}$ 2,03011 dan nilai signifikan $0.004<0.05$. Berdasarkan kedua nilai tersebut mengindikasikan bahwa semakin baik Kebijakan Dividen yang mna mampu mempengaruhi rasio pembayaran terhadap 
investor maka akan diikuti meningkatnya nilai perusahaan dimata publik.

3. Hasil penelitian membuktikan bahwa profitabilitas berpengaruh postif terhadap terhadap nilai perusahaan dengan kebijakan dividen sebagai variabel moderating. Hal ini dibuktikan melalui analisis moderating dapat diketahui bahwa hasil uji $t$ untuk variabel moderating menunjukkan bahwa variabel Kebijakan Dividen merupakan variabel moderating dan mampu memperkuat dalam hubungan antara Profitabilitas terhadap Nilai Perusahaan. Hal ini dapat dibuktikan dengan diperoleh nilai t hitung $3,680>\mathrm{t}$ tabel 2,03011 dan nilai signifikansi $0,015<0,05$ yang berarti Kebijakan Dividen merupakan variabel moderating dalam hubungan antara Profitabilitas terhadap Nilai Perusahaan. Nilai t hitung positif artinya berpengaruh positif, yaitu kebijakan dividen dapat memperkuat hubungan antara Profitabilitas terhadap Nilai Perusahaan dengan angka pengaruh sebesar 30,6\% yang dibuktikan melalui uji koefisien determinasi.

\section{Saran}

Berdasarkan dari hasil penelitian, maka peneliti mengajukan beberapa saran sebagai berikut:

1. Penelitian ini menunjukkan bahwa kebijakan dividen mampu menjadi variabel yang memperkuat hubungan anatara profitabilitas terhadap nilai perusahaan sehingga perusahaan hendaknya memperhatikan faktor-faktor yang mungkin saja menjadi tekanan bagi angka pertumbuhan rasio pembayaran deviden yang juga akan berpengaruh secara langsung terhadap kebijakan dividen.

2. Saran untuk perusahaan-perusahaan di BEI (Bursa Efek Indonesia) terutama dibidang disektor industri dasar dan kimia sebaiknya meningkatkan tata kelola yang baik dan disertai dengan kinerja yang baik, sehingga dapat meningkatkan nilai perusahaan dimasa yang akan datang.

3. Dalam penelitian ini untuk nilai perusahaan hanya menggunakan satu alat ukur yaitu PBV (Price Book Value). Diharapkan untuk peneilitian selanjutnya menggunakan beberapa indicator untuk mengukur nilai perusahaan dapat menggunakan PER (Price Eranninf Ratio) atau Tubin's Q.

4. Diharapkan untuk penelitian selanjutnya menambahkan sampel dan tahun penelitian sehingga mampu meningkatkan dan memaksimalkan keakuratan hasil dari variabel intervening ini dikarenakan semakin banyak sampel maka semakin tinggi tingkat keakuratan. Selain itu diharapakan untuk menambah variabelvariabel yang terkait yang mampu mempengaruhi nilai perusahaan.

\section{DAFTAR PUSTAKA}

Ghozali, I., 2013. Aplikasi Analisis Multivariat dengan Program IBM SPSS 
21. Edisi 7, Penerbit Universitas Diponegoro, Semarang. Quarterly Journal of Economics, 128, pp.15471584.

Kasmir, D., 2016. Analisis Laporan Keuangan, Cetakan Kesembilan, PT. Rajagrafindo Persada, Jakarta.

Riyanto, A., 2013. Statistik Deskriptif Untuk Kesehatan. Yogyakarta: Nuha Medika, pp.30-31.

Sari, K.H.W., 2015. Pengaruh Profitabilitas terhadap Nilai Perusahaan dengan Kebijakan Dividen sebagai Variabel Intervening pada Perusahaan LQ45 di
Bursa Efek Indonesia (Doctoral dissertation, STIE PERBANAS SURABAYA).

Sugiyono., 2017. Metode Penelitian Kuantitatif, Kualitatif, Dan $R \& D$. Bandung: ALFABETA, Cv.

Suliyanto, D., 2011. Ekonometrika Terapan: Teori dan Aplikasi dengan SPSS. Penerbit Andi: Yogyakarta.

Timotius, K.H., 2017. Pengantar Metodologi Penelitian: Pendekatan Manajemen Pengetahuan untuk Perkembangan Pengetahuan. Penerbit Andi. 